\title{
Meaning making and resilience among academically high-achieving Roma women
}

\author{
Bálint Ábel Bereményi1 - Judit Durst ${ }^{2}$ \\ https://doi.org/10.51624/SzocSzemle.2021.3.5 \\ Manuscript received: 16 August 2020. \\ Revised manuscript received: 17 December 2020. \\ Acceptance of manuscript for publication: 14 January 2021.
}

\begin{abstract}
This paper investigates the self-narratives of academically high-achieving, first generation college educated, and highly resilient Roma women. We place their meaning making and social navigation processes at the centre of our inquiry, understanding it as an important element of the resilience process of upward mobility (Ungar 2012). Self-narratives describing their changing social class and the corresponding dilemmas offers us the opportunity to understand their strategies, and how to accomplish a resilient minority mobility trajectory, by mitigating the tension and the emotional cost that unavoidably comes with the large social distance they travel between their community of origin and the newly attained class (Naudet 2018).

The article draws on two research projects; the first conducted in Spain (2015-17) among 35 Roma university graduates, and the second in Hungary, (2018-20), between 150 Roma and non-Roma university graduates. We have selected one 'resilient minority mobility trajectory' as an ideal type from each database for the purposes of this comparison. In this category, upwardly mobile Roma graduates achieve their aspired self-development with the minimal 'emotional cost' possible.

Our main argument is that a 'minority path of social ascension', in itself, is not enough to mitigate the high emotional costs of changing social class. It also requires negotiation, meaning making or reframing work. In this thesis, we support Michael Ungar's proposal that resilience during upward mobility is a process in one's ecological context and not an individual asset, and that meaning making work is a crucial part of it. We expand this thesis, however, by demonstrating how navigation among the available resources, and the negotiation of what a 'proper Roma woman' and a 'successful life' means, in the community of origin, plays a crucial part in accomplishing a resilient upward mobility process.
\end{abstract}

Keywords: Spanish Roma, Hungarian Roma, social mobility, resilience, meaning making

\section{Introduction}

Throughout the biographical notes of two young Roma women, a Spanish and a Hungarian, we aim to illustrate the complexity of the personal experience of resilient upward social mobility of a selection of first-generation Roma university graduates,

1 Democracy Institute, Central European University, email: beremenyi.abel@gmail.com

2 Institute for Minority Studies, Research Centre for Social Sciences, Hungarian Academy of Sciences / Department of Anthropology, University College London, email: durst.judit@tk.hu 
who come from socially disadvantaged backgrounds. We term a mobility trajectory 'resilient' when upwardly mobile people narrate their social ascension as having occurred with minimal emotional pain: when the "hidden costs" (Cole-Omari 2003) of social mobility is minimal. Our aim in this paper is to understand the strategies that are utilised to accomplish a resilient minority mobility trajectory by mitigating the tension and the emotional costs that are unavoidable when one travels long social distance between the community of origin and the newly attained class (Naudet 2012).

We have strategically selected one interview from both the Hungarian and the Spanish project for the purpose of this article, in order to give an analytical interpretation of this 'resilient minority mobility trajectory' (Durst-Bereményi 2021) that we have found the most common among our respondents in both countries. On the basis of these two, purposively selected personal accounts, we identify a variety of ways as to how young Roma women navigate among available resources and different social settings and negotiate (Harris-Chu-Ziervogel 2018) and reframe the meanings thereof in order to mitigate dilemmas and alleviate the price of their upward social mobility.

Both selected 'resilient' Roma women constructed a double-bound middle class belonging by conducting an incorporation into mainstream society similar to what scholars call the distinctive 'minority culture of mobility' (Neckerman-Carter-Lee 1999, Vallejo 2012, Shahrokni 2015). They managed to make the mobility aspirations of their parents a reality through high academic achievement, in contrast to those who did not enjoy such explicit family support, or those who chose non-academic paths to achieve social mobility. Drawing on a thorough analysis of the narratives of these two women, we argue that adaptation in shifting from one social-institutional setting to another through navigation, negotiation, meaning making and reframing, beyond their personal resistance, played a crucial role in their mobility path.

These resilient individuals also paid emotional, social and cultural costs for their upward social mobility (Bereményi 2018), nevertheless multiple factors potentiated them throughout their life to recover and benefit from the effect of adversities. Individuals in this category tend to assign unequivocally positive meaning to their mobility processes. In this sense, the notion of resilience is central to our analysis in order to understand patterns of their "resilient minority mobility trajectory" (Durst-Bereményi 2021).

Our empirical findings support the idea that resilience is a multi-dimensional process (rather than an asset) that potentiates positive development in adverse situations (Ungar 2012). Resilience represents "the capacity of a system to absorb disturbance, undergo change, and retain the same essential functions, structure, identity, and feedbacks" (Resilience Alliance's definition cited by Longstaff et al. 2010) Thus, resilience is framed in the capacity of social and physical ecologies in order to provide opportunities for recovery and positive adaptation in the presence of risk factors. 
The intent to construct a coherent narrative of resilient mobility trajectories is full of contradictions among mismatching 'ideologies' (Vallejo 2012, NeckermanCarter-Lee 1999, Bereményi-Carrasco 2017) of different cultural and social settings (Durst-Bereményi 2021). Naudet (2012) argues that 'self-narratives' of social success reflect one's intent to reduce those tensions and provide hardship with meaning. "The obligation to reduce the tension leads [...] to another obligation: that of developing a coherent self-narrative and managing to make sense of the trajectory of upward social mobility" (Naudet 2018: 12). Thus, self-narratives through meaning making of adversities, and reframing old, traditional meanings embodied through growing up in their Roma community of origin are not only descriptive data, but more importantly, an integral part of the resilience process itself.

\section{Roma people's mobility chances in different settings: Spain, Hungary}

A cross-country comparison of socially ascending resilient trajectories requires an understanding of national and local contexts. Mobility opportunities in Spain and Hungary have developed in a diverging fashion in the past decades, shaping the chances of socioeconomic progress differently for young Roma people. The Council of Europe recognises that the European Roma Population is worse off than any other minority group in Europe when it comes to education, health, employment, housing and political participation ${ }^{3}$. Academic and policy literature points to ethno-racial discrimination that hinders policies and programmes to improve Roma's situation in these fields (O'Higgins-Ivanov 2006). Furthermore, Roma communities are heterogeneous, due to diverse Roma identities, traditions and community histories, as they have developed in particular political, social and economic contexts.

Since the mid-90s, up until the financial crisis of 2008 followed by a recession, Spain went through an intensive economic development characterized by 'quick, short and incomplete expansion' of the service sector, and the intensive boom of the construction industry, while work productivity remained low (Requena-Stanek 2015: 491). All these factors offered favourable conditions for the social mobility of the poorly trained urban working class, among them the Spanish Roma, called Gitano ${ }^{4}$. The economic and social success of Roma people usually did not lead to cultural capital accumulation (schooling, training, high-quality jobs). Furthermore, paramount demographic changes in the Roma families must also be mentioned (Rodríguez 2011), such as a decrease in birth rates, reduced family sizes and the increase of nuptial age, age of first birth or life expectancy, to mention but a few data (Laparra 2007). The 'Spanish model of Roma inclusion' gained great attention for its good results. However, the improved conditions of the Spanish Roma people

3 https://www.coe.int/en/web/commissioner/thematic-work/roma-and-travellers

4 Spanish Roma is a distinctive social group, beyond its ethnic particularities, in demographical and socio-economic terms as well. 
cannot be linked to ethnically targeting public policies and actions, but rather to the effects of a social protection system that benefited both Spanish Roma and nonRoma citizens (Rodríguez 2011, D’ALEPH-FSG 2008) within a particular period of unsustainable economic growth, that was favourable for a low-skilled labour force. Recent economic crises affected Roma citizens earlier, more harshly and for longer than non-Roma citizens (FSG 2013, Fundación Secretariado Gitano 2020). Even if Spanish Roma had access to tertiary education in growing numbers, the proportion of individual graduates is still at 2,2\% of the $20-24$ years old Spanish Roma population; in comparison with approx. $21,5 \%$ of the total Spaniards in this age-group (FSG-CEET 2013).

In Hungary the trend of increasing social fluidity ${ }^{5}$ between 1973-83; and its consolidation between 1983-92 turned around from 1992 to 2000 in an economic downturn and at an increasing level of unemployment (Kertesi-Kézdi 2010). The Roma population in the state-socialist Hungary was almost fully employed as unskilled or low-skilled workers (Csepeli-Örkény 2015). The post-socialist transition caused a destruction of most low-skilled work places, and resulted in a drastic drop in the employment rate among the Roma (Kertesi-Kézdi 2010). By the early 90s, the ethnic employment gap reached 40 percentage points (idem). The social mobility chances for Roma have practically stalled during recent decades (Zolnay 2018, Róbert 2019). The broad ethnic gap has manifested in the field of higher education, too. Meanwhile almost one-fifth of Hungarian people possess a university degree, only 3.3 per cent of Roma have graduated from a higher education institution according to the latest census (National Statistical Office 2015).

The diverging socioeconomic processes of Spain's and Hungary's Roma population in the past four decades make the findings of this paper particularly interesting. The fundamentally different opportunity structures of these countries shaped different intergenerational mobility trajectories, that also affect the ways young Roma women make sense of their resilient life-course, and how they construct their mobility self-narratives. The Spanish context of EU accession created an economic boom and represented an opportunity for the working class to achieve significant social mobility locally. In Hungary, the democratic transition for many caused impoverishment and downward mobility for the working classesand for lowskilled Roma people. Mobility opportunities have been made through geographical mobility, especially for people coming from rural Hungary to the capital city or for those going abroad. In this sense, we found that a geographically fixed upward social mobility trajectory produced a self-narrative vis-à-vis the locally set negotiations over resources and meanings (of our Spanish interlocutor) while a geographically highly mobile trajectory (of our Hungarian protagonists) gives meaning to its

5 Social fluidity or relative mobility 'concerns the relationship between class origins and current class position based on the comparison, between the chances of people of different class origins of being found in one destination class rather than another' (Breen 2004: 4). 
ascendant mobility process in an intellectually and socially broader frame in which local community is substituted by a wider range of sociocultural references.

\section{Antecedents and conceptual-analytical framework}

\section{Minority groups and social mobility}

Research on social mobility consistently highlights the role of ethnicity/race and the diverging mobility patterns among different minority groups (Loury-ModoodTeles 2005). From an economistic perspective mobility in the primary labour market is reported to be more difficult for stigmatised ethnic/racial groups, and above average for "model minorities" (Wu 2014, Zhou-Xiong 2005), highlighting that low status minority groups may invest in alternative socio-economic mobility patterns, such as self-employment (Portes-Zhou 1992). Within the contextual complexity, discrimination paradigm (Loury-Modood-Teles 2005) underlines that the conditions of ethnicity and race affect social mobility, basically, in two ways: firstly, with how the majority society makes decisions on the life chances of minorities based on their negative/positive perception respecting their habits, attitudes and skills. Secondly, ethnicity and race may reflect real social formations (networks, reciprocity, solidarity, like-mindedness, etc.,) that can impact habits, attitudes or skills which partially determine social mobility (Loury-Modood-Teles 2005). From an identity-based approach, these authors emphasise that if these groups are "constituted by a rich set of ethnically or racially specific institutions [they] are likely to have more control of these processes of meaning production", while groups with weaker institutions are likely to find their identity produced at least as much by outsiders as by themselves (Loury 2002). This latter idea recalls Ogbu's cultural-ecological theory (Ogbu-Simons 1998) on how minority groups develop cultural models (that is add meaning, and adapt action) of schooling adapting to the double pressure of systemic factors (interethnic relations, misrecognition, glass ceiling, etc.,) and community forces (aspirations, expectations adjusted to societal experiences). The model calls attention to the tensions between diverse, or even contrary meanings assigned to an object, a behaviour or an institution, and how individuals struggle with navigating or negotiating among those meanings. Portes and Zhou's (1993) term of selective acculturation or Gibson's (1988) accommodation without assimilation describe these strategies along social mobility process of minorities. Beyond apparent gains, upward mobility paths often imply concomitant 'prices' (Friedman 2016), 'emotional cost' (Reay 2005, 2015), 'psychological strain' (Neckerman-Carter-Lee 1999), or in an umbrella term, 'hidden costs' (Cole-Omari 2003) particularly among minorities. In earlier works we have developed this aspect with respect to Spanish (Bereményi 2018, Bereményi-Carrasco 2017) and Hungarian Roma (Durst-Bereményi 2021, Durst-Fejős-Nyírő 2014). Here we focus on meaning making or framing as a coping strategy of these challenges. 


\section{Roma high-achievers and resilience}

The vast majority of studies on Roma academic high-achievers (Abajo-Carrasco 2004, Kende 2007, Bereményi 2018, Mendi 1999, Tóth et al. 2016) aim to identify factors and conditions that foster upwardly mobile trajectories, or identity change related issues, and they tend to overlook the related resilience process.

A few, however, have incorporated resilience as a central issue. Máté (2015) argues that resilient Roma persons constantly respond to the (perceived) compulsion to conform, which pushes them towards a larger than average mobility range. Eventually, this extraordinary effort triggers difficulties in coping with double or multiple identities. Dimitrova et al. (2014) claim that ethnic 'identity is particularly important for Roma as a way of coping with adverse conditions and to enhance their resilience' (2014: 378). Forray (2016), following a more traditional objective, focuses on the description of those ecological protection and risk factors that foster the resilient trajectories of vulnerable Roma youth that 'make it' against the odds. From a different perspective Györbíró et al. (2015) pay attention to the 'community resilience' of the Roma people, the underlying adaptation to changing mainstream societal conditions, and the capacity to define its own needs and to negotiate their attainment (2015: 124). Finally, Székelyi et.al (2005) offer a detailed description of how successful Roma interpret society and their own success, conditioned by the range of their mobility.

Our interest here is somewhat different. We aim at understanding how academically high achieving 'first generation intellectual' (Ferenczi 2004) Roma women make meaning, and give a coherent sense of their 'resilient minority mobility trajectory', through their self-narratives. In our inquiry we focus on mobility self-narratives of personal, social and physical resources, and opportunity structures throughout their resilient trajectories. We identify a variety of ways in which young Roma women navigate among these resources and social settings and negotiate and reframe the meanings thereof in order to 'mitigate the price' of their upward social mobility.

\section{Resilience from an ecological perspective}

Resilience, a central concept in our study, has traditionally been used to describe individual traits of coping in adverse situations. Towards the 1980s, the main focus was growingly placed on the interaction of those traits with their physical and social environment (Rutter 1987 in Ungar 2011). From an ecological perspective, instead of 'resilient individuals,' investigations tend to highlight physical and social conditions that help individuals cope with horizontal and vertical stressors successfully. In this way, resilience can be understood as 'the ecologically complex' (multi-dimensional) processes that people engage in, that makes positive growth possible, all of which are dependent upon the capacity of social and physical ecologies to provide opportunities for positive adaptation (preferably in ways that express prosocial collective norms) in adverse conditions. Following Joseph's (2013) definition, 'ecological and social 
components' are linked by complex resource systems such as economic systems, institutions and organisations. Resilience provides these complex systems with the ability to withstand and survive shocks and disturbances. It also emphasises the capacity for renewal (Joseph 2013: 39). Similarly, Ungar's (2012) analytical model highlights the role of the following 4 factors: personal strengths and challenges; ecology; available and accessible opportunities; and meaning creation.

In an educational context, academic resilience gained general consolidation recently, when OECD's PISA test introduced this dimension in 2011 (Patakfalvi-CzirjákPapp Neumann 2018). OECD's definition ${ }^{6}$ fosters an ecological approach through the concepts of 'resilient schools' (Day-Gu 2013, Patakfalvi-Czirják-Papp-Neumann 2018) or 'academic resilience' in terms of institutional (Széll 2018) and systemic (EcclestoneLewis 2014, Tóth et al. 2016) conditions that make students' development possible.

\section{Meaning making}

Drawing on Ungar (2012), 'meaning creation', or 'meaning making' (Lamont 2000), or 'framing' has a central role in our analytical framework. The concept of 'frame', originally coined by Goffman (1974), is based on the idea that the same reality is perceived by different individuals differently, depending on their previous experiences and understanding (Small-Harding-Lamont 2010). Thus, a frame does not only structure how we interpret events, but also how we react to them.

Similarly, 'meaning' refers to the culturally framed values and beliefs assigned to given resources that are available and accessible. With Ungar's words 'the meaning we attribute to aspects of our social and physical ecology shape the opportunities that we create' (2012: 22). The likelihood that interactions between individuals and their environments 'will promote well-being under adversity depends on the meaningfulness of these opportunities and the quality of the resources provided' (Ungar 2012: 14). In this context, resources are not 'objectively' useful and supportive for a person, but one's social and cultural environment may create an interpretation of them, or frame them as supportive or not, as (morally, technically, etc.,) acceptable or not, as accessible or not, and if so, to what extent. For example, Small (2002) shows that an individual's participation in a housing project does not depend on the degree to which the residents value community participation as such, but rather on the frame through which they view the neighbourhood's change as a result of their historical demands. So, previously uninvolved citizens first need to reframe their understanding of the neighbourhood before they become active participants. In this sense, "frames define horizons of possibilities, individual life projects, or what is thinkable" (Small-Harding-Lamont 2010: 15).

Certainly, resilience process includes an individual's capacity to reframe these given meanings or navigate their way to a wide range of resources, as well as their

6 OECD (2018) Academic resilience: what schools and countries do to help disadvantaged students succeed in PISA. OECD Working Paper no. 167. EDU/WKP(2018)3 http://www.oecd.org/officialdocuments/publicdisplaydocumentpdf/?cote=EDU/ WKP(2018)3\&docLanguage $=$ En 
individual and collective capacity to negotiate for the meaning of those resources, or their provision in socially and culturally acceptable ways (Ungar 2012). Navigation refers to the capacity to identify and access those resources, while negotiation supposes entering into interaction to redefine, reframe, and legitimise alternative cultural meanings thereof (Harris-Chu-Ziervogel 2018). However, both concepts highlight the active engagement of individuals in the resilience process, that necessarily imply trade-offs rather than win-win scenarios (Renn-Schweizer, 2009 in Harris-ChuZiervogel 2018). With respect to the socially upwardly mobile individual who chooses to highlight his attachment to his group of origin, Naudet claims that he seeks 'to prepare a space in which this "accursed share" of his social origins can be activated' (Naudet 2018: 19). This latter effort is an overt effort of negotiation.

In the meaning making process Naudet (2018) and others (Carter 2005, Vallejo 2012, Neckerman-Carter-Lee 1999, Friedman 2016, Baxter-Britton 2001) draw attention to the conflicts and moral dilemmas socially upwardly mobile people struggle with, by oscillating between their attachment to the background of origin and their efforts to legitimise their attained social position. Upward mobility for socially disadvantaged individuals implies a 'mastery over schemes of action and perception that are differently situated in the social space, and hence in contradiction with each other' (Naudet 2018: 11).

Based on these perspectives and notions, we focus on meaning making or framing of the elements of minority mobility process, relying on Ungar's (2012) social ecological approach to resilience. In particular, we centre our attention on the strategy of navigation, the capacity to identify and access resources and negotiation, the interaction with their background of origin in order to redefine, reframe and legitimise alternative meanings of resources and the conditions of accessing it (Harris-Chu-Ziervogel 2018).

\section{Methodological notes}

The Spanish dataset contains 35 purposively selected interviews with male and female first-generation Roma professionals, while the Hungarian set includes 45 (out of the 150 -Roma and non-Roma respondents). Data collection was made through semi-structured, narrative, in-depth life course interviews. We considered our interviewees Roma based on their self-ascription. We reached them through personal networks and utilising the snowball technique. Verbal informed consent was obtained at the beginning of the interviews, in a recorded form.

For the purpose of this paper, we selected one interview from each of these two datasets stemming from two research projects conducted in Spain ${ }^{7}$ and Hungary. ${ }^{8}$

7 Project entitled "School Success among the Roma in Romania and Spain. Conditions, trajectories and consequences" conducted in the frame of an agreement between the Universitat Autònoma de Barcelona (Spain) and the Romanian Institute of Research on National Minorities (Romania). 2016-2018

8 Ongoing project entitled "Social mobility and ethnicity: Trajectories, outcomes and hidden costs of mobility", supported by the Hungarian Academy of Sciences' (NKFHI) research grant (no. K-125 497), 2018-2021. 
We chose them as they represent one of the most typical mobility paths identified in both projects; that is, what we call the 'resilient minority mobility trajectory'. A particularity of the two selected interviewees presented in this text is that, beyond the interviews, their trajectories have been followed up throughout the past years, through a series of informal meetings.

After conducting thematical analyses of different subsets of the Hungarian and Spanish data, for the purposes of this paper, we explore the problem of meaning making within single settings in order to obtain a more nuanced interpretation through narrative analysis.

We purposefully chose female Roma informants as our preliminary analyses showed that they have to negotiate even more issues and reframe more traditional meanings during their mobility trajectories than men do. The analysis of the databases showed that many women in traditional Roma communities face stricter control of their families and ethnic communities. In the case of women, parents play a more complex role of being shock absorbers or mediators in their communities. Due to tighter restrictions and controls, female youth tend to negotiate more sophisticated manners than their male protagonists, and to navigate with more agility, and they often imply a wider range of intervening agents. Most importantly, they need to negotiate their aspirations for further studying (to a higher educational level) against their ethnic community's control and under pressure to (not) conform to the gendered expectations of them about getting married (as a virgin) and starting a family at a young age. For these reasons, Pantea (2015) calls young Roma women who managed to persuade their traditional Roma communities to allow them to have access to university (to an unknown and therefore dangerous terrain) as "skilled navigators".

In our analysis we use the case study approach. 'In this approach, the data is interpreted within the unique context of each case in order to provide an account of a particular instance, setting, person, or event [...]'. In case studies, categorising occurs 'within a particular case rather than across cases, so that the contextual relationships are harder to lose sight of' (Maxwell-Chmiel 2014: 26).

Throughout the paper, our aim is to explore how people tell the story of their mobility experience, so we applied a narrative analysis (Esin-Fathi-Squire 2013). Following Naudet (2018), creating a self-narrative of success can never claim to be objective, because of the risk of the imperfection of memory, the potential attempt of reconstructing the past, the inevitable strategies of the interviewee to present himself in a better light and to make sense of all his ordeal. However, for sociologists, goes on Naudet, social facts include discourses. In this sense, what we aim is to find out is how interviewees narrate their negotiations, navigations, meaning making and reframing of traditional meanings in their discourses and how they use a selfnarrative of mobility as a means to resolve tensions lived through the mobility experience (Naudet 2018). 
Having recognised the importance of the interactions among systems components, our unit of analysis in this inquiry is the meaning making process of our respondents: their individual virtues, their agency, but also of the social and physical ecological settings they oscillate between, and the interaction among these elements (Bronfenbrenner 1979).

\section{Results}

This analysis focuses on two Roma women's life courses, both from the analytical category that we earlier coined 'resilient minority mobility trajectory' (DurstBereményi 2021). Each trajectory is unique, but Saray's ${ }^{9}$ and Jutka's cases point to important elements of an ecological model of social resilience. The experience of resilient mobility certainly differs in range and quality of resources in women from those of men, but strategies to navigate towards them and negotiate their meaning differ as well. So, our intention is to highlight processes of meaning making and reframing old meanings within the process of social and physical ecology of resilience. Saray's trajectory concentrates a wider than average range of ecological and individual elements which offer a rich case-study to analyse navigation and meaning-making dynamics of minority social mobility in the Spanish context. Similarly, Jutka's life-course is embedded in a particularly dense ecology of opportunities that makes a long-range mobility possible with supportive structures. At the same time, both success stories are a result of coping with - among others ethnic- and gender-specific costs.

\section{Saray (Spain)}

Saray, a 26-year old Spanish Romani young woman became widely known for having completed her MA in Economics at a prestigious private university in Barcelona, and for her public speech in the Catalan Parliament's special International Roma Day event. She grew up in Barcelona's most deprived and stigmatised, geographically segregated residential complex, let's call it "La Salud", with strikingly low employment, education and health figures. Saray's grandparents, migrated from Southern Spain in search of a better economic situation, but faced substandard housing conditions that gradually improved. His grandfather even went to work in France and Switzerland in the 70s and 80s. Saray's father quit school early and mostly did integrated jobs with non-Roma colleagues as self-employed or as an employee. Her mother combined marginalised and mainstream jobs. She studied in labour market access programmes and recently obtained a special driving licence to drive a compact street sweeper at her job.

9 All names are pseudonym to ensure research participants' anonimity 
Saray led her life through a rich variety of physical, social and cultural settings, receiving contradictory messages from her nuclear family, extended family, local ethnic community and neighbourhood, from the mainstream society institutions and non-Roma peers. Her parents' unconditional support and her older brother's academic trajectory helped her navigate among resources coming from all these contexts, and to negotiate meanings that often caused her conflicts and dilemmas stemming from her in-between position.

\section{[Family]}

Her mother mobilised her limited social capital in order to foster Saray's academic career. A person from a Jehovah's Witness congregation volunteered to help them with school homework in primary school. Later on, a middle-class lady whose house Saray's mother cleaned, helped Saray and her brother financially in order for them to access a prestigious semi-private high school. Monthly tuition fees were well above their economic possibilities, but her parents made it somehow. 'My mom wanted us to leave the neighbourhood...' says Saray. She responding to her parents' expectations and studied hard, becoming obsessive about getting good marks. It was an extraordinary effort undertaken to conclude the mobility ambitions of earlier generations. On her blog she notes ${ }^{10}$ :

“The 'Revolución Gitana' is nothing new... It's something that our grandparents started, that our parents continued... With the sole objective of destroying the ceiling that limited the future of our people."

This self-conscious struggle against structural inequalities emerged in her at a mature age, once her ethnic activist identity will have appeared. Nevertheless, her family's support for mobility was a fundamental experience for Saray throughout her childhood, just like her older brother's example, the first in his family who finished high-school and achieved a BA degree.

Her parents prepared her to cope with differential treatment both for being a Roma and for living in La Salud.

"My mother used to say: 'If you are asked whether you are a Gitana [Gypsy], you just say that you are a person. So that they don't prejudge you."

At home, she received a gender education that fitted that of the mainstream society, but at a certain point in her teenage years, her parents decided to apply the rules of 'Roma virtue' to her, as it was defined by more traditional segments of the extended family and local community: a 'decent Roma young female' should not be out of the

10 Saray's website was closed recently, due to the high cost of maintenance 
sight of her family; should not mix with 'unauthorised' young males (neither Roma, nor non-Roma); should focus on domestic tasks; should preferably not remain in school after 'coming of age'; and should fit the Roma aesthetic norms (long hair, etc.). Nevertheless, these gendered expectations are far more relaxed as regards young males. She overtly rebelled against the unexpected and unprecedented gendered control.

\title{
[Extended family]
}

Her main allies in everyday border crossing (both in a symbolic and a geographical sense) were her ethnically mixed cousins from her father's side, living next door, who disregarded their Roma origin almost completely.

\footnotetext{
"We all used to go to school together... with my cousins of the neighbourhood [...] Those of my mom's side went school, too, but they didn't give it the same importance."
}

The cousins from her mother's side tended to call into question the relevance of school with respect to social mobility.

\begin{abstract}
“They used to tell my brother: 'Why on earth do you study all the time?'... 'Going so much to school' [...] They didn't give you any support, well. But I didn't really take them into account."
\end{abstract}

As a response to the double-bind messages in her extended family, Saray further strengthened her disciplined, work-focused attitude with respect to school-related activities. Her everyday success, from both her teachers and non-Roma peers, and their positive feedback deepened her faith in meritocracy.

\section{[Local Ethnic Community and wider Roma population]}

Local Roma community members often questioned the relevance of long years of school by contrasting it with economic outcomes. Saray's daily symbolic and physical border crossing generated criticism in some community members who even accused her of not behaving properly as a Roma young woman: particularly with respect to mixing with non-Roma, and with males. She also narrates symbolic elements of the community control:

\footnotetext{
"It's not that they tell you that it's not OK that you still go to school. But you notice it. For example, when I come from the university, I usually carry a backpack to put my university folder inside. I carry only one folder. But I'm ashamed. Because you see that people look at you because you carry a folder and it's not normal. You can perceive it."
} 
In order to cope with this shameful situation, she changes her look every time she crosses the neighbourhood borders: earrings, cardigan and the bag. She navigates among different cultural codes in order to fit expectations, to avoid criticism, and to gain recognition in diverse social settings. She is convinced that, as a way of getting ahead socially, one needs to 'go out of' La Salud and its limited public services. Good education, safe playgrounds or public transport are anywhere, but beyond La Salud.

"What I think is that those who value education should go outside the neighbourhood."

She also refers to community pressure that limits one's expectations and horizons. It did not only impact Saray but also her parents. In her adolescent years, her parents attempted to restrict her social life according to Roma community gender rules, as never before. Saray describes it as a turning point. Drawing on earlier life experiences, she recognised multiple layers of community oppression and control and she was determined not to obey them.

"The questions people pose you... make you feel uncomfortable. If a non-Gypsy person asks you, “Ah, are you still studying?” Well done. But if a Gypsy person asks you "Are you still studying?" It's like... you know what he's thinking..."

With the latter, Saray refers to the criticism of elderly Roma, as teenage girls are expected not to return to school after their 'coming of age' anymore. During the compulsory studies, Saray managed to respond to multiple expectations, but as a teenager, resistance emerged with respect to nuclear and extended family, as well as the local Roma community:

"They asked you that you had to act like that because you were a Gypsy and you have to do this and that... Well, no! ... That's when I realised... Who doesn't want to look at you because you don't do what they want... Well, no... I've always been very independent. [...] If you don't like it, then I don't know... if I'm sure and I see it that way, I'm going to do it."

Saray's resistance to community rules, and her academic success linked to a progress in the labour market within and outside the 'Roma domain', eventually put her in a respected position among the elderly leaders. She was even asked to give a speech in the Parliament of Catalonia on the International Roma Day on two occasions. Despite Saray's brave (self-) criticism, Roma elderly, and particularly Roma women, loved her presentation. 
"I didn't expect the Roma to like that. I knew that the Payos [non-Roma] would like the speech. But the Roma [...] As I had never felt that the Roma... that they cared about my opinion. Because 'you are not Roma..., right?"

From a resistant stance and due to her success achieved outside of the 'Roma field', Saray was able to renegotiate not only her position within the Roma community and Roma 'civil society domain', but also to reframe the meaning of being a 'proper young Roma woman', and her role within the minority struggle.

"You suffer a series of things that you don't know very well. Well, and when you are clear about what you're going to do, being a Roma doesn't mean that discomfort. I think, other [non-Roma] women don't have these problems."

\section{[School and mainstream society]}

A crucial setting where Saray elaborated her resilient mobility path was school. Saray followed her brother and cousins to a semi-private school in an adjacent, non-segregated neighbourhood, which ensured her a higher academic standard and access to non-Roma peers with social mobility aspirations through academic continuity. She obtained a group of good friends who became her main referents. This way, an otherwise difficult decision regarding a post-compulsory school choice was easy for her. Saray has not only exceled in establishing good relationships with teachers and friends, but also in adjusting the pace of mobility and acculturation. On finishing her Baccalaureate studies, and exhausted by attention to her school-works, she decided to slow down and complete an advanced vocational education course in Administration and Finance.

"I was determined not to go to university, even if my teachers disagreed. [...] I ended up very tired... I didn't feel like deciding in two months what to do... everything was like very unknown. I was tired and I didn't want to start a four-year thing without being sure."

By this decision she entered into a negotiation between her fears, fatigue, higher academic and labour market aspirations, possibilities of the school system and a series of contradictory external expectations, all these aspects deeply affected by an ethnically and social class-biased thinking. Saray tried to negotiate the speed of her distinctive mobility path, resisting external pressure. She opted to slow down and to advance with short steps.

High school and university for her meant hard work and knowledge accumulation and she left very little room for networking, entertainment or emotional support.

"I liked people with whom I could talk about homework, right? I didn't like the typical girls who talked in the schoolyard. They bored me." 
"I'm a bit obsessive about homework... With these guys [university mates of immigrant origin] I feel very comfortable because they also go there to study." For Saray, school, teachers and schoolmates transmitted the meritocratic frame of studies linked to social mobility. In opposition, networking and socio-effective bonds did not belong to her to the meanings assigned to advanced studies.

"Many people think: look, party, and just party-time and all this. But not for me. For me university was money and stress."

In order to follow the stressful rhythm that university required, she enrolled in an expensive private support centre where she received individualised attention to pass her university exams. Not only did Saray navigate among contradictory expectations, but she also decided to reframe the terms with her teachers, peers, family and local community. It is her social environment that created experiences that pushed her to this direction. Saray narrates several examples. When a teacher made an anti-Roma comment in class, she saw to it, in the finish, that the teacher apologised. Similarly, by choosing finance and economy studies, she challenged Roma NGOs and local community members' push towards studies in the domain of social or health assistance, through which she renegotiates Roma women's symbolic roles and opportunities in post-compulsory studies.

\section{[Ethnic Activism Scale]}

Sara re-elaborated her Roma ethnic belonging by working for a Roma NGO for a year. At the NGO, Roma colleagues pushed her towards the capitalisation of her academic success and Roma belonging at a grassroots level. Nevertheless, she aspired to access the labour market in her own right, via her accumulated merits. She is proud of having obtained a job in the public administration in her field of expertise (tax management) through fair competition without any ethnic favouritism and, reaffirmed in her belief in meritocracy, she continued her ethnic activism through her personal blog, and occasional public speeches in which she vindicates Roma participation in decision-making processes at all levels.

Finally, it is crucial to note that Saray got married to a non-Roma ex-school friend from La Salud, who partnered her throughout the last decade employed as a maintenance technician - well beneath her educational and labour market status. They went to live to an adjacent town where they had a baby. She continues to feel more comfortable in La Salud, but at the same time, she feels frustrated with the unchallenged conservative female role of main caregiver that hinders her high career potential. 


\section{Jutka (Hungary)}

Jutka was born in the Roma settlement situated in a small village in Southwest Hungary, some $250 \mathrm{~km}$ from Budapest. Her successful mobility trajectory eventually took her to live in Barcelona where she worked for a multi-national company. Statesocialist policies offered her grandfather a mainstream job, which made it possible for them to settle down on the edge of a village. Jutka's father completed a vocational course in locksmithing, her mother in social work and administration. Her father's short career as a football player helped them leave the settlement and move closer to the village centre, and later to move to the county capital city. Eventually, both parents managed to get a temporary job in Germany, an old dream of theirs. Jutka's growing independence and career - linked to the vivid opportunities related to the Roma issue in Hungary at that time (Havas 2006) - began in boarding school at the age of 12; continued at the university in Budapest; then to a well-paying job; became focused through a Roma-internship at the European parliament; a Master's programme at a prestigious private university; another Roma-related job at a Hungarian Ministry; back to Brussels; and to the UK. Finally, somewhat burnt out, she settled down in Barcelona far from the Roma issues, working for a private enterprise.

\section{[Family]}

The unrealised schooling plans of Jutka's parents were transformed into high aspirations and a strong family support towards her studies, even at a high emotional price.

"Both of my parents had very strong expectations... Mom's, Dad's biggest dream was that we all three [children] graduate from university."

Jutka actually was not interested in continuing education. Her mother played a key role in mobilising all possible resources - a scholarship, family support, public announcements, and so on. - that all helped Jutka get further on and geographically farther away from home. But Jutka's inner motivation towards the university eventually came from outside.

Jutka's parents are proud and self-conscious Roma, but they did not devote much attention to Roma identity questions in their children's education. Their assimilated lifestyle prioritised social progress to ethnic attachment. Jutka did not mention any traditional gendered expectations from her parents.

\section{[School]}

Jutka went to an integrated local elementary school. Till the age of 10 she did not notice any signs of discrimination. 
"When my mother saw my [bad] grades, she went to my school and scold off all the teachers. [...] Then I began to feel that something here was not the same for me as it was with the others."

In 6th grade she moved to a boarding school, a recently launched Roma magnet school in a distant city. Her social environment radically changed, and she lost contact with villagers. Large city, autonomy, strong ethnic identity support and, especially, the attention of caring tutors created an ideal condition for her growth and positive Roma identity formation. At the age of 17 , she found herself in a preparatory entry course to a Budapest university, where she eventually began a BA in Social Policy.

"I saw a Roma guy who was not only a college student, but he was at ELTE ${ }^{11}$... it meant something to me[...] The more he talked about sociology, social policy in that course, the more I started to become interested in it and I say 'it could be absolutely great."

Thanks to her mother's intervention, a wealthy person - linked to a political party - offered to finance her entire BA studies with all the expenses covered. After her graduation, this Maecenas also helped her obtain a well-paying job in a bank. The hidden agenda of Maecenas was to engage Jutka in party political activity, but Jutka skilfully resisted it without losing her support. While working, she kept investing time and energy in 'human capital' enhancement through further Master programmes.

[Mainstream peers]

Living in a capital city and studying at a university with an intellectually stimulating environment pushed her towards the development of her own agency in her social mobility.

"University is freedom and party [...] I made very good friendships, and it was then that the world expanded for me [...] For the first time in my life I drank beer [...] I was on an exploratory tour for two years."

Educational progress became meaningful beyond academic investment. Jutka assigned to it a profoundly social meaning: enjoying a colourful world of friendships from diverse social origins. Despite the unresolved crises of belonging, she increasingly recognised her own capacity to navigate among resources. Though her mother's pushy support never ceased to influence her:

11 An old and prestigious, top university in Budapest 
"And by then my mother had started, that 'Daughter, I read an article here that there are Roma programmes at the X University ${ }^{12}$. [...] I go. You just have to learn English, my daughter. It will work. Intermediate level. It's not a big deal'."

Against her mother's pressure, Jutka was going to reduce speed, and say 'no' to further stimulation.

"Then I was like, oh my God, again with this stuff, another university, I had enough with those five years..."

She chose to work in a bank thanks to her contacts with Maecenas, but as she felt unprepared for the job she enrolled in a specialising course. Soon, she was selected for an internship in the European Parliament, closely related to the European Roma Strategy, so she left the bank. After this and thanks to the European experience, eventually, she signed a contract with the Hungarian Ministerial division responsible for the Roma inclusion strategy. After these 'zigzags' she got accepted and began the Roma access programme her mother had suggested, at X University.

"Well, let's give it a try... and this is what I call awakening [...] as if I had been asleep until then. [...] The way of thinking, this critical look at the other side of everything that they taught us there..."

The Roma access programme and the subsequent MA in social policy, with high academic standards, strong ethnic identity and emotional support, and a vibrant international human environment meant a turning point for her and her future career in different supranational agencies and European universities. We can observe, how the unprecedented opportunity boom pushes her forward at an incredible speed in a relatively narrow tube: the Roma issue. Also bearing in mind her academic efforts, the ethnic opportunity structure helped her in the labour market, irrespective of strong existing gender and ethnic gaps (Fodor-Glass 2018). As for her private life, however, Jutka does not consolidate a lasting supportive emotional partnership. Instead, she widens her cross-border network of friendships.

\section{[Roma community]}

Jutka's successful trajectory hid her identity struggle based on the dilemma between external expectations and her personal experiences of being a Boyash Roma. In her family it was not at all a central issue.

"We did not have much contact with Gypsy neighbours, only [with] the family. [...] We kept close contact with our close cousins, but not beyond that."

12 A prestigious international private university in Budapest 
The main concern for the family was rather socio-economic mobility and making the most of upcoming opportunities.

"At a very young age, we became quite independent of the family."

So, it was not until boarding school (a Roma-support magnet school) that she faced her Boyash Roma ${ }^{13}$ origin as opposed not only to non-Roma but also to other Roma identities.

"I knew I was a Gypsy, but there was no value attached to it. [...] There were ninetynine per cent Gypsy students there. I started to realise it [ethnic identity] there... “

At the university she was accused by peers of benefiting from positive discrimination. Furthermore, in different situations, non-Boyash Roma confronted her with the supposedly inferior status of Boyash with respect to other Roma subgroups.

"I applied to Gypsy organisations, and they were constantly asking me, 'but what kind of Gypsy are you?' I tell them, Boyash. 'Ah.... You know, these unspoken..., what might have had no importance at the time. But I did see what I wanted to see into it. "

The talent nurturing Roma majority magnet school, as well as the MA course in public policy made her available resources to put the puzzles of ethnic belonging together. Finally, she managed to consolidate a coherent narrative on what being a Roma meant to her and how she managed to make it up.

"Then this Gypsy identity went very hard on me. It was very contrary to the Hungarian identity, and I didn't understand how on earth the two could be harmonised. The X [university' Roma access programme] and my life abroad helped a lot in it."

Being a Roma also filled her career goals with a particular meaning: the desire to give something back to the community. In her narrative it seemed to help ease mobility-related pains and dilemmas. Although she does not make it clear what the community is for her.

“...it was already in my mind that if I finish this, I would give something back to the community."

13 One of the Roma subgroups in Hungary, the Boyash keep their distinctive ethnic identity, and language (ancient Romanian) as opposed to Vlah and Romungro subgroups (Bódi 1997, Szuhay 2002) 
She does not detail why and how she aimed to 'give back'. She proceeded quickly in jobs related to the Roma inclusion programmes, both in Hungary and in Brussels, thanks to her strict work ethics, high aspirations, thorough training and her personal commitment to the Roma issue. She did not experience any 'ethnic ceiling', she was able to make the most of her ethnicity as an asset in a particular labour market.

[Navigation, negotiation and resistance]

Jutka had decisive agency in adjusting the pace and resisting options that may have caused an inacceptable burden on her well being: even during the first BA years in the capital city, personal well-being prevailed over academic obligations. She learnt from her mother an extraordinary ability to navigate among resources. However, she has gradually developed her own capacity to negotiate meanings and means by gaining awareness of how social mobility operates. Her mother's outstanding capacity to set the next goal and achieve resources to it, is a valuable capital that Jutka has taken from home and progressively developed for herself during her journey to university and further. Repeated geographical mobility and an ever present need to move on to new challenges is a sign of her capacity to navigate among sources of resilience in any setting and a footprint of her parents push towards new and more challenging situations in the hope of mobility.

"I'm always going to keep on moving, I can't stop, this is the problem... my longing for knowledge..."

Another more abstract example for her navigation capacity can be tracked in her struggle with her ethnic identity. Earlier we could observe the steps of her gendered ethnic and national identity formation in different social contexts towards other Roma people and the non-Roma, up to the point that she considered it resolved, finally.

"By then... I had learnt to handle it, so I didn't care about what they said [...] Now, I don't have that problem anymore."

While she assumed different tasks of 'giving back', she refused to do it in the Hungarian political scene in everyday politics. While she managed to develop a complex ethnic/national and gender identity for herself in a racist and anti-Gypsy context, she avoided everyday confrontation (with fellow-students or co-workers):

"But overall, we did not confront [with fellow students] ... we knew that professionals, by the way, were absolutely racist."

Similarly, once her mission related to Roma projects in Europe finished, she decided to move on to jobs away from the ethnic encapsulation. In all the above issues, Jutka developed a lineal narrative from more complex, problematic situations toward their successful solution through an active negotiation of their meaning. She emphasises, 
beyond her active agency and merits, her parents role in her upward mobility, and also the role of the accessible protective agents or organisations (such as her private Maecenas; the Roma-support magnet school; and the Roma Access Program). But she also reveals that while mastering a successful mobility path, she struggles with a lack of a settled lifestyle with respect to jobs, romantic relationships and forming a family.

Her social mobility trajectory follows a highly multi-faceted pattern, where national, ethnic, gender and class identities are at stake, which eventually gave way to a more pluralistic, cosmopolitan mobility project, where navigation, negotiation and resistance turned into key skills.

\section{Concluding discussion}

Both young Roma women of this article, coming from socially disadvantaged family backgrounds show resilient patterns of social mobility, i.e. a positive personal development despite adversities; achieving upward social mobility with relatively low 'emotional costs'. They took the mobility path to which most Roma academically high achievers belong to in our datasets, a 'resilient minority mobility trajectory' (Durst-Bereményi 2021). It means that they followed a distinctive incorporation into the majority middle class, keeping their ethnic identity and desiring to give something back to their respective Roma communities, in whatever they define it.

Both Roma women enjoyed strong family support and built intra- and interethnic alliances throughout their high-achieving academic paths, as opposed to those who did not enjoy such explicit support, or those who chose non-academic paths to achieve social (economic) mobility. Their parents role as mediators and stress-absorbers with respect to their community's ethnic culture driven gendered expectations is crucial in Saray's case. Jutka's parents stand out in prioritising social mobility to local ethnic community links and corresponding gender roles.

From the informants' narratives we can learn how social and physical ecological factors (such as unequal gender relations; discriminative treatment; obedience to community's elderly; age-related social roles; crossing neighbourhood borders for example,) were given alternative meaning by these Roma women, sometimes in opposition to the norms and beliefs of their community of origin, through navigation, negotiation and reframing. Also, we were able to observe how they have intended to construct their coherent self-narratives on their own resilient mobility trajectories with contradictions and tensions among the 'ideologies' of the community of origin and those of the attained social group, or among different social fields.

The focus of our analysis was not to observe how particular factors in these social/ institutional settings contribute to resilient trajectories, but to understand how our subjects meaning making and reframing of traditional meanings (for example about further studying; aspiring to a high-status job or 'being a proper Roma woman') 
operates as part of a resilience process that reduces the tension and the emotional price of their large range of upward mobility.

In these Roma women's trajectories close family members tended to offer greater support for mobility, through the transmission of an 'ideology'14 that fits mainstream society's normative expectations: for instance, a strong individualistic and meritocratic stance is present in both narratives. We argue that our protagonists are under a complex and dynamically changing set of ideological influences by at least family, ethnic community and mainstream society. These opposite ideological influences are complemented by the messages from their peers, different members of the mainstream society they regularly encounter, and also of their protective, supportive agents or mobility supporting organisations they belonged to at one period during their mobility journey. Multiple ideology mismatches in different ecological settings, or within the same, eventually crystallise in 'self-narratives of mobility', attempting to 'render a trajectory marked by contradiction coherent' (Naudet 2018: 12). Through that, meaning making of resources and opportunity structures of one's mobility constitute an important element of their resilience process.

Saray's central motif can be described through the symbol of 'revolución gitana' [Roma revolution], a self-narrative that recognises the past social mobility and acculturation process of previous Roma generations at a very high cost, as the root of her present success. This narrative calls for both challenging structural forces (she focuses on 'Roma [job]ceiling', but also mentions ethnic discrimination) and changing mentality and habits of Roma young people within a clearly meritocratic framework, where effort and sacrifice can supposedly break through those ceilings. In her self-narrative Saray does not focus on her system-challenging collective actions. She emphases the need for reframing folk theories of success, including her community of origin's frames about the 'thinkable horizon of possibilities' (SmallHarding-Lamont 2010: 15) for Roma women, with respect to education, training, labour market and belonging to an ethnic community. Furthermore, Saray describes her resilient mobility trajectory as a negotiation for resources and meanings within the triangle of a) her supportive nuclear family and like-minded 'non-Roma cousins', b) her extended Roma family and local Roma community of origin, and c) her attained mainstream society's middle-class values.

First, her trajectory is presented as a triumph in navigating towards 'non-Roma' ideological, institutional, social and material resources and in actively negotiating meanings with teachers, peers and colleagues. Her older brother - as an academic pioneer in the local Roma community - helped her avoid painful lessons, such as with the more adequate and marketable choice of the BA course. Her experience

14 Following Geertz, ideology is 'the attempt [...] to render otherwise incomprehensible social situations meaningful, to so construe them as to make it possible to act purposefully within them, that accounts both for the ideologies' highly figurative nature and for the intensity with which, once accepted, they are held.' (Geertz 1973, 220). 
of university as a place of knowledge accumulation, where no joyful activities were legitimate was undoubtedly a negotiated stance for Saray.

Secondly, the self-narrative is complemented with a moral victory celebrated over sceptical sectors of her local Roma community that initially challenged and even sanctioned her mobility ambitions (more importantly for being a young woman with high aspirations) and questioned her true Romaness. Eventually they acknowledged her achievements and began to 'use' her on broad platforms in order to highlight talent and effort within the Roma community. This victory, in the end, justifies the conflicts and dilemmas and reframes the painful feeling of in-betweenness (neither Roma, nor Paya; neither from La Salud, nor from integrated neighbourhoods) as a source of freedom on the path of alternative meaning making.

Thirdly, she recognizes her family's role as a buffer, defending her against her community of origin's accusation of 'betraying the Roma origin' by 'becoming an educated Paya [no Roma],' and also, skilfully mediating between ethnic community cultural wealth (Yosso 2005) and mainstream ideologies; facilitating the coherence between family dynamics and participation in wider societal and institutional settings. She also mentions her family members as 'social resources' (Michèle LamontWelburn-Fleming 2013) in coping with everyday misrecognition, stereotyping, stigmatisation, or discrimination, recurring both individual and collective responses: both ethnic pride and rights, and individualistic meritocratic competition.

Conflicts inevitably emerged with respect to all three arenas and among them, but in Saray's narrative, thanks to her increasing agency (keeping range, speed and direction of mobility under control) she managed to cope with them successfully. Her short-term work at a Roma NGO helped her, on the one hand, elaborate a coherent discourse on how an academically high-achieving Roma woman from La Salud can remain a 'proper Roma woman', on the other, legitimate her new status among the Roma through linking academic knowledge with acts of contribution to the community's well-being. Due to Saray's geographical immobility, her selfnarrative is evolving with reference to local/regional Roma community experiences.

As opposed to Saray, Jutka's central motif in her mobility self-narrative is geographic mobility that downplays the local community's influence in the complex ideology negotiation. Behind her nuclear family's geographical mobility there was an explicit motivation of upward social mobility and acculturation. Her parents' ambitions also inspired Jutka's move to a distant Roma talent nurturing secondary boarding school in a large city at an early age, and later, to Hungary's capital city and other European metropolitan cities. It eventuated in the loss of direct contact with her local community of origin, and its substitution by school-based (non-Roma) peer communities and an intellectually reconstructed and more broadly framed Roma ethnic belonging. Peers and the professional communities that surrounded Jutka supported her family's belief system with respect to the link between educational attainment and social mobility. Facing recurrent dilemmas, in these constantly 
shifting contexts, Jutka had the chance to renegotiate her ideology system in increasingly complex settings among ethnically diverse Roma ${ }^{15}$ peers, elite Roma activists, Roma NGOs, intellectual academic tutors and peers, and her politically active Maecenas. Her main experience of misrecognition or discrimination stems from other than Boyash Roma colleagues and university peers. Her main tool to cope with these situations was accommodation over confrontation (Lamont-WelburnFleming 2013).

Macro-level opportunity structures and resources played a central role in her socially and geographically mobile trajectory: both through earlier generation's making the most of the state-socialist system's inclusive school and labour market policies, and in her own generation's exceptionally vibrant pro-Roma and NGO activity and policy implementations in the '90s - early 2000. Jutka mastered her capacity to occasionally slow down and take her time in order to assume and capitalise on recent growth and repeatedly remake her life amidst changing contexts. Due to high geographical mobility, she self-narrated her mobility in an intellectually and socially broader framework in which her background of local ethnic community has been losing its role as a reference point, but being substituted by an international Roma community on the basis of their shared history of oppression.

The main differences of the self-narratives between the two Roma women can be observed in the meaning they assign to local Roma community and Roma/nonRoma peers. The fact that Jutka crossed a much broader range and variety of social arenas and settings throughout her education and professional trajectory made her more sensible to the interpretative frameworks of Roma and non-Roma peers, and less exposed to the cultural or ideological pressures of her local Roma community. Spending her adolescence in different schools and dormitories far from home, she was compelled to revise, adjust or renegotiate meanings assigned to elements of social mobility, more frequently. In this sense, while in-betweenness represents a source of freedom anyway (Naudet 2018: 23), Saray enjoyed this freedom of meaning making and social participation under the vigilance of the local Roma community, Jutka engaged in this process under less direct control, implying more adjustments to nationally and internationally diverse settings.

Our paper can be read as an argument supporting the idea, illustrated by the examples of our two Roma woman protagonists, that resilience is a process that one's social and physical ecology facilitates. We explored resilient mobility trajectory as 'the ecologically complex (multi-dimensional) processes that people engage in, that makes positive personal growth possible (engaging in higher education, resisting prejudice, creating networks of support, solving identity and the wider dilemmas caused by the huge range of upward mobility), all of which are dependent upon

15 She recognises diversity among Roma sub-groups, such as Vlach, Boyash and Romungro . 
the capacity of social and physical ecologies to provide opportunities for positive adaptation in adverse conditions.

Given the example of the two Roma women, we argued that not only personal strength, and good navigation and negotiation skills but available and accessible resources are the essential factors necessary to accomplish a resilient mobility trajectory. However, in recent day Hungary and Spain where mobility seems to have stalled, and the recourses necessary for educational mobility are restricted for those coming from socially disadvantaged families; personal strength, navigation skills and resilience to adversities are not making up for the loss of structural opportunities of a resilient upward mobility for many unprivileged Roma.

\section{References}

Abajo, J. E. - Carrasco, S. (2004): Experiencias y trayectorias de éxito escolar de gitanas y gitanos en España. Encrucijadas sobre educación, género y cambio cultural. Madrid: CIDE/Instituto de la Mujer.

Baxter, A. - Britton, C. (2001): Risk, identity and change: Becoming a mature student. International Studies in Sociology of Education 11(1): 87-104. https://doi.org/10.1080/09620210100200066

Bereményi, B.Á. (2018) Costes de la movilidad entre gitanas y gitanos con trayectorias académicas de éxito. In Andrés, R. - Maso, J. (ed.): (Re)visiones gitanas. Políticas, (auto)representaciones y activismos en diálogo con el género y la sexualidad. Barcelona: Edicions Bellaterra, 137-171.

Bereményi, B. Á. - Carrasco, S. (2017): Bittersweet success. The impact of academic achievement among the Spanish Roma after a decade of Roma inclusion. In Pink, W. T. - Noblit, G. W. (ed.): International Handbook of Urban Education. New York: Springer, 1169-1198.

Bronfenbrenner, U. (1979): The Ecology of Human Development. Experiments by Nature and Design. Cambridge, Massachussets, London: Harvard University Press.

Carter, P. L. (2005): Keepin'it real: School success beyond black and white. New York: Oxford University Press.

Cole, E. R. - Omari, S. R. (2003): Race, Class and the Dilemmas of Upward Mobility for African Americans. Journal of Social Issues 59(4): 785-802. https://doi.org/10.1046/j.0022-4537.2003.00090.x

Csepeli, G. - Örkény, A. (2015): Az emancipáció kihívása a mai magyar társadalomban a romák és nem romák viszonyában. Szociológiai Szemle 25(3): 83-102.

D’ALEPH - FSG (2008): Mapa sobre vivienda y comunidad gitana en España 2006-07. Madrid: Fundación Secretariado Gitano.

Day, C. - Gu, Q. (2013) Resilient Teachers, Resilient Schools: Building and Sustaining Quality in Testing Times. In Zhu, X. - Goodwin, A. - Zhang, H. (ed.): Quality of 
Teacher Education and Learning. New Frontiers of Educational Research. Singapore: Springer, 119-144.

Dimitrova, R. - Chasiotis, A. - Bender, M. - van de Vijver, F. J. R. (2014): Collective Identity and Well-Being of Bulgarian Roma Adolescents and their Mothers. Journal of Youth and Adolescence 43 375-386.

https://doi.org/10.1007/s10964-013-0043-1

Durst, J. - Bereményi, B. Á. (2021) 'I felt I arrived home': The minority trajectory of mobility for first-in-family Hungarian Roma graduates. In Mendes, M. M. - Magano, O. - Toma, S. (ed.): Social and Economic Vulnerability of Roma People. Key Factors for the Success and Continuity of Schooling Levels. Heidelberg, New York: Springer, 229-250.

Durst, J. - Fejős, A. - Nyírő, Z. (2014): 'I always felt the odd one out': Work-life balance among graduate Romani women in Hungary. Acta Ethnographica Hungarica 59(1): 165-190. https://doi.org/10.1556/AEthn.59.2014.1.8

Ecclestone, K. - Lewis, L. (2014): Interventions for resilience in educational settings: challenging policy discourses of risk and vulnerability. Journal of Education Policy 29(2): 195-216. https://doi.org/10.1080/02680939.2013.806678

Esin, C. - Fathi, M. - Squire, C. (2013) Narrative Analysis: The Constructionist Approach. In Flick, U. (ed.): The SAGE Handbook of Qualitative Data Analysis. London: SAGE Publications, 203-216.

Ferenczi, Z. (2004) Az elsőgenerációs értelmiség kialakulásának sajátosságai. In Szakál, G. - A. Gergely, A. (ed.): Társadalmi tőke, karrieresélyek, viselkedésminták. Budapest: MTA Politikai Tudományok Intézete, 21-34.

Fodor, É. - Glass, C. (2018): Labor market context, economic development, and family policy arrangements: Explaining the gender gap in employment in Central and Eastern Europe. Social Forces 96(3): 1275-1302.

https://doi.org/10.1093/sf/sox080

Forray, K. R. (2016): Tehetséggondozás a felsőoktatásban. Educatio 25(3): 311-317.

Friedman, S. (2016): Habitus clivé and the emotional imprint of social mobility. The Sociological Review 64 129-147. https://doi.org/10.1111/1467-954X.12280

FSG (2013): El impacto de la crisis en la comunidad gitana. Madrid: Fundación Secretariado Gitano.

FSG - CEET (2013): El alumnado gitano en secundaria: un estudio comparado. Madrid: Fundación Secretariado Gitano, (CNIIE) Ministerio de Educación, Cultura y Deporte. Fundación Secretariado Gitano (2020): Situación de la comunidad gitana por el covid 19 y el Fondo de Emergencia Social de la Fundación Secretariado Gitano, Cadena Ser. Hoy Por Hoy, 22 May,

Geertz, C. (1973): Ideology as a Cultural System. InThe Interpretation of Cultures. Selected Essays. New York: Basic Books, Inc., 193-233.

Gibson, M. A. (1988): Accommodation without assimilation: Punjabi Sikh immigrants in an American high school and community. Anthropology of contemporary issues. Ithaca: Cornell University Press. 
Goffman, E. (1974): Frame analysis. Cambridge, MA: Harvard University Press.

Györbíró, A. - Hámos, M. D. - Györbíró, N. - Borzási, K. (2015): Innovatív reziliencianövelő kísérlet a roma közösségek esetében: A magyarországi roma szakkollégiumok mint a roma értelmiségi elitképzés úttörői. Tapasztalatok és alkalmazható tanulságok az erdélyi oktatási rendszer számára. Erdélyi Társadalom 13(1): 119-128.

Harris, L. M. - Chu, E. K. - Ziervogel, G. (2018): Negotiated resilience. Resilience. International Policies, Practices and Discources 6(3): 196-214.

https://doi.org/10.1080/21693293.2017.1353196

Joseph, J. (2013): Resilience as embedded neoliberalism: a governmentality approach. Resilience 1(1): 38-52. https://doi.org/10.1080/21693293.2013.765741

Kende, A. (2007): Success stories? Roma university students overcoming social exclusion in Hungary. In Colley, H. - Boetzelen, P. - Hoskins, B. - Parveva, T. (ed.): Social inclusion for young people: breaking down the barriers. Strasbourg: Council of Europe Publications, 133-144.

Kertesi, G. - Kézdi, G. (2010): Roma Employment in Hungary After the Post- Communist Transition. Budapest Working Papers on the Labour Market, No. BWP - 2010/9. Budapest: Hungarian Academy of Sciences, Institute of Economics.

Lamont, M. (2000): Meaning-Making in Cultural Sociology: Broadening Our Agenda. Contemporary Sociology 29(4): 602-607.

Lamont, M. - Welburn, J. S. - Fleming, C. M. (2013) Responses to Discrimination and Social Resilience Under Neo-Liberalism: The United States Compared. In Hall, P. A. - Lamont, M. (ed.): Social Resilience in the Neoliberal Age. Cambridge: Cambridge Univ Press,.

Laparra, M. (2007): Informe sobre la situación social y tendencias de cambio en la población gitana. Una primera aproximación. . Madrid: Ministerio de Trabajo y Asuntos Sociales.

Longstaff, P. - Armstrong, N. J. - Perrin, K. - Parker, W. M. - Hidek, M. A. (2010): Building Resilient Communities: A Preliminary Framework for Assessment. Homeland Security Affairs 6(3):. from: https://www.hsaj.org/articles/8 [Accessed:

Loury, G. C. (2002): The Anatomy of Racial Inequality. Cambridge, Massachussets, London: Harvard University Press.

Loury, G. C. - Modood, T. - Teles, S. M. (2005) Introduction. In Loury, G. C. - Modood, T. - Teles, S. M. (ed.): Ethnicity, Social Mobility, and Public Policy: Comparing the USA and UK. Cambridge (UK): Cambridge University Press,.

Máté, D. (2015): Reziliens romák identitáskonstrukciói. Erdélyi Társadalom 1 43-55.

Maxwell, J. A. - Chmiel, M. (2014): Notes Toward a Theory of Qualitative Data Analysis. In Flick, U. (ed.): The SAGE Handbook of Qualitative Data Analysis. London: SAGE Publications Ltd, 21-34. 
Mendi, R. (1999): Felsőoktatásban tanuló roma fiatalok pályaszocializációs és személyiségvizsgálata. Bölcsészkariszakdolgozat. Eötvös Lóránd Tudományegyetem, Budapest.

Naudet, J. (2012): Social Mobility and Explanations for Social Success in France, in the United States, and in India. Sociologie 3(1): 39-59. https://doi.org/10.3917/socio.031.0039

Naudet, J. (2018): Stepping into the elite. Trajectories of social achievement in India, France and the United States. Oxford: Oxford University Press.

Neckerman, K. M. - Carter, P. - Lee, J. (1999): Segmented assimilation and minority cultures of mobility. Ethnic and Racial Studies 22(6): 945-965. https://doi.org/10.1080/014198799329198

O'Higgins, N. - Ivanov, A. (2006): Education and Employment Opportunities for the Roma. Comparative Economic Studies 48(1): 6-19. https://doi.org/10.1057/palgrave.ces.8100147

Ogbu, J. U. - Simons, H. D. (1998): Voluntary and Involuntary Minorities: A CulturalEcological Theory of School Performance with Some Implications for Education. Anthropology \& Education Quarterly 29(2): 155-188.

Pantea, M. C. (2015): Persuading others: Young Roma women negotiating access to university. Education as Change 19(3): 91-112. https://doi.org/10.1080/16823206.2015.1024151

Patakfalvi-Czirják, Á. - Papp Z., A. - Neumann, E. (2018): Az iskola nem sziget. Oktatási és társadalmi reziliencia multietnikus környezetben. Educatio 27(3): 474-480. https://doi.org/10.1556/2063.27.2018.3.9

Portes, A. - Zhou, M. (1992): Gaining the upper hand: Economic mobility among immigrant and domestic minorities. Ethnic and Racial Studies 15(4): 491-522. https://doi.org/10.1080/01419870.1992.9993761

Portes, A. - Zhou, M. (1993): The New 2nd Generation - Segmented assimilation and its variants. The Annals of the American Academy of Political and Social Science 530 74-96.

Reay, D. (2005): Beyond consciousness? The psychic landscape of social class. Sociology 39(5): 911-928. https://doi.org/10.1177/0038038505058372

Reay, D. (2015): Habitus and the psychosocial: Bourdieu with feelings. Cambridge JournalofEducation 45(1):9-23.https://doi.org/10.1080/0305764X.2014.990420

Requena, M. - Stanek, M. (2015): Las clases sociales en España: cambio, composición y consecuencias. In Blanco, A. - Chueca, A. - Bombardieri, G. (ed.): Informe España 2015. Madrid: Fundación Encuentro, 487-517.

Róbert, P. (2019) Intergenerational educational mobility in European societies before and after the crisis. In Tóth, I. G. (ed.): Hungarian Social Report. Budapest: Tárki Társadalomkutatási Intézet Zrt., 120-136.

Rodríguez, I. (2011): The Process of Inlcusion of the Roma Community in Spain: A Model for Europe? In Flašíková-Beňová, M. - Swoboda, H. - Wiersma, J. M. (ed.): Roma: 
A European Minority The Challenge of Diversity. Brussels: Group of the Progressive Alliance of Socialists \& Democrats in the European Parliament, 119-126.

Shahrokni, S. (2015): The minority culture of mobility of France's upwardly mobile descendants of North African immigrants. Ethnic \& Racial Studies 38(7): 10501066. https://doi.org/10.1080/01419870.2014.964280

Small, M. L. (2002): Culture, cohorts, and social organization theory: Understanding local participation in a Latino housing project. American Journal of Sociology 108 $1-54$.

Small, M. L. - Harding, D. J. - Lamont, M. (2010): Reconsidering Culture and Poverty. The ANNALS of the American Academy of Political and Social Science 629 6-27. https://doi.org/10.1177/0002716210362077

Székelyi, M. - Örkény, A. - Csepeli, G. - Boócz Barna, I. (2005): A siker fénytörései. Budapest: Sík kiadó.

Széll, K. (2018) School-related factors of resilience development. In Fehérvári, A. (ed.): School, development, equity. Budapest: HIERD, pp. 93-106. Budapest: HIERD, 93-106.

Tóth, E. - Fejes, J. B. - Patai, J. - Csapó, B. (2016): Reziliencia a magyar oktatási rendszerben egy longitudinális program adatainak tükrében. Magyar Pedagógia 116(3): 339-363. https://doi.org/10.17670/mped.2016.3.339

Ungar, M. (2011): The social ecology of resilience: Addressing contextual and cultural ambiguity of a nascent construct. American Journal of Orthopsychiatry 81(1): 1-17. https://doi.org/10.1111/j.1939-0025.2010.01067.x

Ungar, M. (2012) Social Ecologies and Their Contribution to Resilience. In Ungar, M. (ed.): The Social Ecology of Resilience. A Handbook of Theory and Practice. New York: Springer, 13-32.

Vallejo, J. A. (2012): Socially Mobile Mexican Americans and the Minority Culture of Mobility. American Behavioral Scientist 56(5): 666-681. https://doi.org/10.1177/0002764211433807

Wu, E. D. (2014): The color of success: Asian Americans and the origins of the model minority. Princeton, New Jersey: Princeton University Press.

Yosso, T. J. (2005): Whose culture has capital? A critical race theory discussion of community cultural wealth. Race, Ethnicity and Education 8(1): 69-91. https://doi.org/10.1080/1361332052000341006

Zhou, M. - Xiong, Y. S. (2005): The multifaceted American experiences of the children of Asian immigrants: Lessons for segmented assimilation. Ethnic and Racial Studies 28(6): 1119-1152. https://doi.org/10.1080/01419870500224455

Zolnay, J. (2018): Commuting to segregation the role of pupil commuting in a Hungarian city: Between school segregation and inequality. Szociológiai Szemle 28(4): 133-151 